Res Balticae, 5, 1999, pp. 75-80.

\title{
DOUBLE CONSONANTS IN OLD PRUSSIAN
}

\author{
FREDERIK KORTLANDT \\ Leiden
}

In an earlier study (1974) I noted that double consonants were particularly frequent before stressed long vowels in the Enchiridion, e.g. semmēe, weddè, billit, seggit, skellānts, dessimts, stallèmai, turrïlai, epwarrisnan, enwackēmai, aupaickēmai, serrīpimai, ettrāi, tickrōmai, dellīkans, isranckisnan, sallübi gennämans, tennä, tennēison. Considering that it is a priori more probable that double consonants occur under the same conditions in word forms without a macron as they do in word forms where we can derive the place of the stress from the macron, I hypothesized that a double consonant may be an indication of stress on the following vowel. In support of this hypothesis I adduced the remarkable alternation between $e$ and $a$ before a double consonant, e.g. in dat.pl. wirdemmans, waikammans and 1st pl. giwemmai, giwammai, also wertemmai, 2nd sg. giwassi, which is easily explained as a result of pretonic neutralization, as in nom.sg.f. tenna $\bar{a}$, tann $\bar{a}$, also acc.sg. gennan, gannan, nom.pl. gennai, gannai, acc.pl. gennans, gannans. I also argued that the hypothesis enables us to derive the Old Prussian accentual system from its reconstructed Balto-Slavic origins.

Comparing the place of the macron in the Enchiridion with the place of the stress in Lithuanian and Slavic, $I$ argued that all three languages underwent a progressive accent shift, but not under the same conditions. On the one hand, the stress shifted to the desinence in semmē, wedde, but not in Lith. žêmé, vẽde. On the other hand, the stress did not shift in āusins, rānkans, as opposed to Lith. ausis, rankàs. I proposed that in Prussian, a stres sed short vowel lost the ictus to the following syllable and added that this rule may have 
applied to stressed short vowels in open syllables only. The rule differs from Dybo's law for Slavic, where a stressed short or circumflexed vowel in a paradigm with fixed stress lost the ictus to the following syllable, and from Saussure's law for Lithuanian, where the shift depended on the intonation of the following syllable. As a result of the progressive accent shifts, twaia has the same stress as Russ. tvojá, where tvoë points to final accentuation as a result of Dybo's law. The same holds true for tennā, Russ. oná, onó. The medial stress in gennāmans corresponds to Russ. žená, acc.sg. ženú, with final accentuation as a result of Dybo's law. If the above hypothesis about double consonants is correct, we have to assume fixed stress on the second syllable throughout the paradigm: gen.sg. gennas, acc.sg. gennan, nom.pl. gennai, acc.pl. gennans. Note that the hypothesis was put forward without regard to the accentual system and that the stress shift was formulated without reference to the hypothesis. Elsewhere I have argued that the Prussian accent shift, like its Lithuanian counterpart, was comparatively recent (1988: 90).

It goes without saying that the use of double consonants to indicate that the following vowel was stressed cannot be attributed to a conscious effort on the part of the writer to mark the place of the stress. It must rather be derived from the German use of double consonants to indicate that the preceding vowel was short. While German words usually had fixed stress on the initial syllable, Prussian had mobile stress and reduction of unstressed vowels. This is the origin of the so-called "Vortondoppelung" which is found in Lithuanian documents from Prussia (Bense 1958: 657): «Ein einfacher Konsonant wird unmittelbar vor dem Ton verdoppelt, wenn der ihm vorausgehende Vokal kurz ist. [...] Doppelschreibung steht auch, wenn im Paradigma Tonwechsel auftritt und der Ton auf den Vokal vor dem zu verdoppelnden Konsonanten fallen kann, aber nur dann, sobald dieser nicht den Ton trägt». Thus, we find turreti, zvinnoti, darryti but 3rd pret. padare, nom.pl. mattydami but pamatę, gen.sg. swétimo and acc.pl. 
swétimus versus nom.pl. swettimi, acc.sg. Métq versus loc.sg. Mette, etc. (cf. also the forms cited in Bense 1998). The same usage is evidently found in the Enchiridion.

My interpretation of the double consonants in the Enchiridion has recently been challenged by Alessandro Parenti (1998: 136), who is evidently unaware of Bense's work. Parenti points out correctly that the Prussian use of double consonants goes back to the German usage of double consonants after short vowels and that the difference between the two systems results from the difference between fixed stress in German and mobile stress in Prussian. However, his assumption that e.g. gemmons and kittan had initial stress because these forms have initial stress in Lithuanian (Parenti 1998: 135) is wrong because he does not take the Prussian accent shift into account. The discrepancy between semmè, wedd $\bar{e}$ and Lith. žẽmé, vẽdè, like that between āusins, rānkans and Lith. ausis, rankàs, suffices to show that the Prussian accent cannot be established on the basis of the Lithuanian evidence. While Parenti maintains that «double consonants cannot be considered as stress marks» (1998: 136) and that «the suffix -senna may be the form successively reduced to -sna by syncope" (1998: 139), he unexpectedly raises the objection that the spelling with double $n$ in -senna «is evidence, though not cogent, that the stress falls on the preceding syllable» (1998: 139). It appears that he was confused in his own mind because in spite of the counterevidence emanating from his own theory he stuck to the traditional view which he rejected three pages earlier. It is remarkable that Parenti does not even mention the Prussian accent shift, let alone the philological and comparative evidence which has been adduced for the relation between Prussian accentuation on the one hand and the East Baltic and Slavic material on the other.

Dismissing my explanation of the frequent alternation between $e$ and $a$ before double consonants as the result of a pretonic neutralization, Parenti claims that the alternation is not limited to 
unstressed syllables and adduces the suffix -sannien, -sennien, -senin and the ending of geitien, geitin, geitan to show that there was no opposition between / e/ and /a/ after consonants (1998: 139). These examples are quite irrelevant because several different morphological formations are involved here (cf. Kortlandt 1997: 158). As I have argued in detail elsewhere (1998a, 1998b), we must be careful in distinguishing between the linguistic systems of the three Old Prussian catechisms and their spellings. Parenti also adduces butten (1x) beside buttan (7x) as an example of $e$ for etymological $a$ after a double consonant (1998: 136), without informing his readers that butten is from the second catechism, where $e$ for $a$ is frequent, while buttan is from the first (1x) and the third (6x) catechisms. The consistent spelling of buttan in the Enchiridion shows that there was no neutralization of /e/ and /a/ in this word: He adduces tennen ( $2 \mathrm{x}$ ) beside tennan ( $8 \mathrm{x}$ ) as another example of $e$ for etymological $a$ (1998: 136) without specifying the context of these forms. The two instances of tennen occur in the following phrases: stēimans maldans Warnins quai tennen enwackē "Den jungen Raben die jhn anruffen" and ainan pogalban teckint kawida surgi tennen boüsei "einen Gehülffen machen die vmb jn sey". Both instances are clearly in syntactic positions where they are unstressed.

Parenti further observes that beside kadden ( $2 x)$ we find kaden (9x), again without specifying the context (1998: 136). The two instances of Kadden are both found at the beginning of a paragraph, where we may expect an explicit spelling. There are also two instances of Kaden at the beginning of a paragraph, whereas kaden is consistently spelt with a single consonant in the middle of a sentence (6x in the Enchiridion and $1 x$ in the second catechism). Note that the Vortondoppelung is also found in kadda and tadda in the Lithuanian documents from Prussia (Bense 1958: 658). The form dabber, which occurs only once in the Prussian material, probably had the same vocalism as kadden, as distinct from Lith. dabar r, kadà. Once again I have to emphasize that an 
internal analysis of the Prussian material must logically precede a comparison with the East Baltic languages because the latter automatically leads to a bias in our interpretation of the data. Crucial evidence remains hidden in the texts if we do not take our primary sources seriously.

\section{References}

Bense, Gertrud. 1958. Sprachliche Untersuchungen zu neugefundenen litauischen Dokumenten aus dem XVIII. Jahrhundert. "Wissenschaftliche Zeitschrift der Martin-Luther-Universität Halle-Wittenberg, Geschichte-Sprachwissenschaft", 7/3, 653663.

Bense, Gertrud. 1998. Studien zu einem preußisch-litauischen Text des 18. Jahrhunderts: die "Kinderlehre" von 1735. Baltistik: Aufgaben und Methoden (Heidelberg: Winter), 259-267.

Kortlandt, Frederik. 1974. Old Prussian accentuation. "Zeitschrift für vergleichende Sprachforschung", 88/2, 299-306.

Kortlandt, Frederik. 1988. Van Wijk's Altpreussische Studien revisited. "Studies in Slavic and General Linguistics", 12, 89-97.

Kortlandt, Frederik. 1997. Baltic $\bar{e}$ - and $i / j \bar{a}$-stems. "Baltistica", 32/2, 157-163.

Kortlandt, Frederik. 1998a. The development of the Prussian language in the 16th century. Baltistik: Aufgaben und Methoden (Heidelberg: Winter), 55-76.

Kortlandt, Frederik. 1998b. The language of the Old Prussian catechisms. "Res Balticae", 4, 117-129.

Parenti, Alessandro. 1998. Old Prussian abstract nouns in -sna, -senna, -sennis. Baltistik: Aufgaben und Methoden (Heidelberg: Winter), 129-142. 


\section{Double consonants in Old Prussian}

\section{Frederik Kortlandt (Leiden)}

Double consonants are particularly frequent before stressed long vowels in the Enchiridion. If double consonants occur under the same conditions in word forms without a long vowel, a double consonant may be an indication of stress on the following vowel. This hypothesis is supported by the remarkable alternation between $e$ and $a$ before a double consonant and enables us to derive the Old Prussian accentual system from its reconstructed Balto-Slavic origins. The Prussian accent cannot be established on the basis of the Lithuanian evidence. An internal analysis of the Prussian material must logically precede a comparison with the East Baltic languages because the latter automatically leads to a bias in our interpretation of the data. 